ppi $201502 Z U 4645$

Esta publicación científica en formato digital es continuidad de la revista impresa ISSN-Versión Impresa 0798-1406 / ISSN-Versión on line 2542-3185Depósito legal pp $197402 Z$ U34

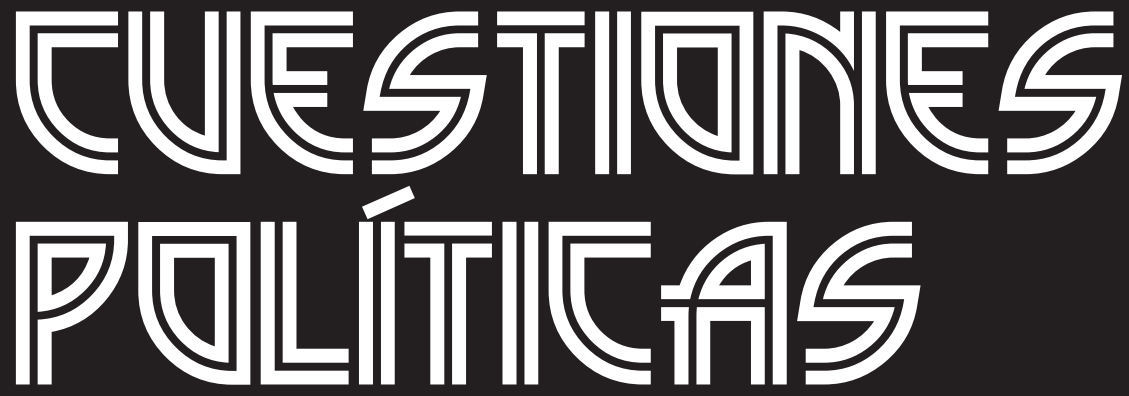

Instituto de Estudios Políticos y Derecho Público "Dr. Humberto J. La Roche" de la Facultad de Ciencias Jurídicas y Políticas de la Universidad del Zulia Maracaibo, Venezuela
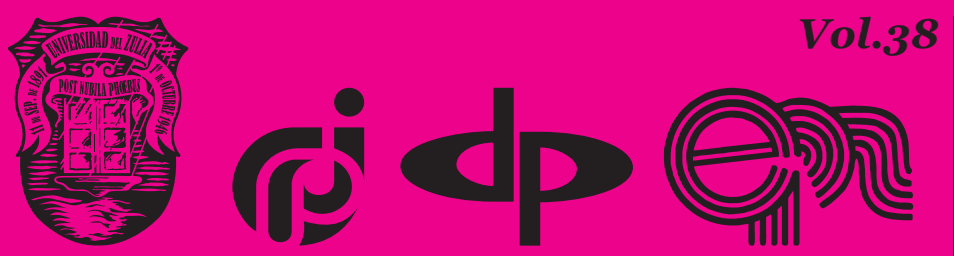

$N^{\circ}$ Especial 1era Parte 2020 


\title{
State Guarantees of the Right to Housing for War Veterans: Substantive and Procedural Aspects
}

\author{
DOI: https://doi.org/10.46398/cuestpol.38e.15
}

\author{
Andriy P. Cherneha * \\ Zhanna $\dot{V}$. Udovenko ** \\ Nataliia A. Sergiienko *** \\ Nataliia O. Oblovatska **** \\ Alyona O. Dotsenko *****
}

\begin{abstract}
The purpose of the article was to reveal the problematic aspects of the realization of the right to housing by war veterans who participated in counter-terrorism operations / joint operations. I am interested in observing the protection of this right in civil, criminal and executive proceedings based on national and international law. The methodological basis of the study includes general and special methods of scientific research (historical, statistical, formal logic, comparative legal and structural logic). Statistics are given on the number of war veterans (combatants) as of 2019-2020, in the dynamics of providing them a living space in Ukraine during 2015-2020. In addition, the article provides examples of the elimination of conflicts of laws and ambiguous judicial practices of application of civil, family, housing and social law, as well as civil, criminal and executive procedure in the field of exercise of the right to housing by combatants and their families, protection of this right before the courts and execution of decisions in this category of cases. The results of this work can be useful for combatants who need to improve their living conditions, as well as for human rights defenders who
\end{abstract} help these people.

\footnotetext{
* Ph.D. in Law, Associate Professor at the Department of Public and Private Law, Borys Grinchenko Kyiv University, Ukraine. ORCID ID: https://orcid.org/oooo-ooo1-5016-6998. E-mail: ov.chernukha@ tanu.pro

** Ph.D. in Law, Associate Professor at the Department of Criminal Law and Criminal Procedure, National University of "Kyiv-Mohyla Academy", Ukraine. ORCID ID: https://orcid.org/oooo-0002-4100-0723. Email: zh-udovenko@ust-hk.cn

*** Ph.D. in Law, Senior Lecturer at the Department of Public and Private Law, Borys Grinchenko Kyiv University, Ukraine. ORCID ID: https://orcid.org/oooo-ooo2-6681-5961. Email: nata-ss@tanu.pro

**** Master's in law, Senior Lecturer at the Department of Public and Private Law, Borys Grinchenko Kyiv University, Ukraine. ORCID ID: https://orcid.org/oooo-0002-7405-279X. Email: oblpvatskan@tanu. pro

*****Master's in law, Senior Lecturer at the University College of Borys Grinchenko Kyiv University, Ukraine. ORCID ID: https://orcid.org/oooo-0oo1-5785-8604. Email: lena.dotsenko@nuos.pro
} 
Andriy P. Cherneha, Zhanna V. Udovenko, Nataliia A. Sergïenko, Nataliia O. Oblovatska y Alyona O. Dotsenko

Keywords: right to housing in Ukraine; war veterans; social security policies; substantive and procedural aspects; obstacles to the enjoyment of fundamental rights.

\section{Garantías estatales del Derecho a la Vivienda para los Veteranos de Guerra: Aspectos Sustantivos y Procesales}

\section{Resumen}

El propósito del artículo fue revelar los aspectos problemáticos de la realización del derecho a la vivienda por parte de los veteranos de guerra que participaron en operaciones antiterroristas/operaciones conjuntas. Intereso observar la protección de este derecho en procesos civiles, penales y ejecutivos con base en el derecho nacional e internacional. La base metodológica del estudio incluye métodos generales y especiales de investigación científica (histórica, estadística, lógica formal, legal comparada y lógica estructural). Las estadísticas se dan sobre el número de veteranos de guerra (combatientes) a partir de 2019-2020, en la dinámica de proporcionarles un espacio vital en Ucrania durante 2015-2020. Además, el artículo brinda ejemplos de eliminación de conflictos de leyes y prácticas judiciales ambiguas de aplicación del derecho civil, familiar, habitacional y social, así como del procedimiento civil, penal y ejecutivo en el ámbito del ejercicio del derecho a la vivienda por parte de los combatientes y sus familias, protección de este derecho ante los tribunales y ejecución de las decisiones en esta categoría de casos. Los resultados de este trabajo pueden ser útiles para los combatientes que necesitan mejorar sus condiciones de vida, así como para los defensores de derechos humanos que ayudan a estas personas.

Palabras clave: derecho a la vivienda en Ucrania; veteranos de guerra; políticas de seguridad social; aspectos sustantivos y procesales; trabas al goce de derechos fundamentales.

\section{Introduction}

Ukraine is a social and law-based state. Human rights and freedoms and guarantees thereof shall determine the essence and course of activities of the State. The State is responsible to the individual for its activities. Affirming and ensuring human rights and freedoms shall be the main duty 
of the State. Human rights and freedoms are inalienable and inviolable. Constitutional human rights and freedoms are not exhaustive, guaranteed and cannot be revoked or limited, except as provided in part one of Art. 64 of the Constitution of Ukraine (2015). According to the Constitution of Ukraine (2015), an individual, his or her life and health, honour and dignity, inviolability and security shall be recognised in Ukraine as the highest social value. And the rights of citizens to social protection (Art. 46), to housing (Art. 47), to a sufficient living standard for them and their families (Art. 48), to health care, medical care and health insurance (Art. 49) are recognized as the most important among other social rights (Kerimov et al., 2015; Kerimov et al., 2018a; Kerimov et al., 2018b).

According to Art. 47 of the Constitution of Ukraine (2015), everyone has the right to housing. The State shall create conditions enabling every citizen to build, purchase, or rent housing. Citizens in need of social protection shall be provided with housing by the bodies of State power and local selfgovernment, free of charge or at a price affordable for them in accordance with law. No one shall be arbitrarily deprived of housing other than on the basis of the law pursuant to a court decision. In case of violation of the rights, including the right to housing, they are subject to protection, in particular, before court, in accordance with Art. 124 of the Constitution of Ukraine (2015) stating that the jurisdiction of the courts shall extend to all legal disputes that arise in the State. Art. 129-1 of the Constitution of Ukraine (2015) prescribes that a court decision is binding. The State ensures the execution of a court decision in the manner prescribed by law. This shows the close connection between judicial and executive jurisdictional activities and their fundamental purpose - to restore the violated rights.

The right to housing is enshrined in international law of the United Nations and the Council of Europe. Paragraph 1 of Art. 25 of the Universal Declaration of Human Rights (1948) proclaims the right of everyone to a standard of living adequate for the health and well-being of himself and of his family. The necessary standard of living provides housing. In paragraph 1 of Article 11 of the International Covenant on Economic Social and Cultural Rights (1973), States Parties have recognized the right of everyone to an adequate standard of living, including housing.

This right is also established by paragraph 31 of Part I and specified by Art. 31 of Part II of the European Social Charter (revised), 1996, that have been ratified by the Law of Ukraine (2006) "On Ratification of the European Social Charter (revised)". In accordance with Art. 31 of Part II of the Charter, states undertake to take measures designed to promote access to housing of an adequate standard; to make the price of housing accessible to those without adequate resources. The human right to housing is universally recognized, and it is, like other constitutional rights, inalienable, inviolable and equal for all without any restrictions on grounds 
Andriy P. Cherneha, Zhanna V. Udovenko, Nataliia A. Sergïenko, Nataliia O. Oblovatska y Alyona O. Dotsenko

of race, color, political, religious or other beliefs, sex, ethnic or social origin, property status, place of residence, custom etc. It may not be repealed or limited, except as provided by the Constitution of Ukraine (Kerimov et al., 2018c; Kerimov et al., 2019).

The state guarantees combatants and persons equated to them a provision of living space on preferential (priority) or extraordinary basis. The issue of exercising such a right has become especially relevant since 2015, when the state budget began to allocate up to UAH 1 billion to improve the living conditions of war veterans (combatants) who took part in antiterrorist operation (ATO)/joint forces operation (JFO) and members of their families. For example, 1,071 apartments were purchased for a total value of UAH 909.5 million during 2016-2017. In 2018, it was planned to purchase 356 apartments for a total value of UAH 354.8 million, including 29 apartments for a total value of UAH 25 million for combatants who have a status of internally displaced persons. According to the budget for 2018, almost UAH 200 million were directed to the programme of providing housing to combatants who took part in hostilities on territories of other states, and UAH 100 million for housing for internally displaced persons (Housing issue, 2017).

In 2019, the Cabinet of Ministers of Ukraine approved a decision to redistribute funds and purchase about 500 apartments for combatants who took part in antiterrorist operation (ATO)/joint forces operation (JFO), internally displaced persons, Maidan participants and families of deceased soldiers (The government has allocated funds for 500 apartments for antiterrorist operation participants, displaced persons and Maidan residents, 2019). For 2020, the government has established monetary compensation in the form of a subvention from the state budget to local budgets for providing housing to people who need to improve their living conditions for the total value of more than UAH 750 million (For the first time in 5 years, 2019).

At the end of 2018, according to the information received from departmental committees on granting the status of combatants to those who took part in antiterrorist operation (ATO), 346,340 people were granted the status of combatant. This number consists of people who performed their duties under the Ministry of Defence - 234,605; the Ministry of Internal Affairs - 32,481; the National Guard - 33,409; the Security Service of Ukraine - 10,745; the Foreign Intelligence Service - 39; the State Border Service - 19,549; the State Special Transport Service - 2,397; the State Security Department - 472; the State Service for Special Communications and Information Protection - 826; the State Emergency Service - 5056; the Prosecutor General's Office - 311; the National Police - 5444 and the State Fiscal Service -826 (The number of anti-terrorist operation fighters who received the status of the participant of hostilities is counted, 2018). In two 
years, as of the end of 2019 - beginning of 2020, the number of those who took part in antiterrorist operation has increased by $15 \%$, and today it is more than 370 thousand soldiers (The number of participants in hostilities was counted by the ministry of veterans, 2019).

The main guarantees for provision of housing to combatants (war veterans, those who took part in antiterrorist operation (ATO)/joint forces operation (JFO) are provided by the Law of Ukraine (1993) "On the Status of War Veterans, Guarantees of their Social Protection"; Law of Ukraine (1991) "On Social and Legal Protection of Servicemen and their Families", the Housing Code of the Ukrainian SSR (1983) and the Resolution of the Cabinet of Ministers of Ukraine (2018c) "Provision of housing to certain categories of individuals who participated in hostilities on the territory of other states, as well as to members of their families"; Resolution of the Cabinet of Ministers of Ukraine (2018d) "Provision of housing to internally displaced persons who defended the independence, sovereignty and territorial integrity of Ukraine"; Resolution of the Cabinet of Ministers of Ukraine (2019) "On approval of the Procedure of using funds allocated from the state budget for provision of preferential long-term state credit for purchasing a housing to internally displaced persons, combatants who took part in antiterrorist operation (ATO)/joint forces operation (JFO)".

\section{Materials and Methods}

The methodological basis of the study includes a system of general and special methods of research designed to obtain its objective and reliable results. The specifics of the purpose and objectives of the study necessitated the use of the following methods: dialectical, legal comparative, legal history, formal logical, system structure, statistics, and others. The leading method that was used to study this problem is the method of modelling, which allows us to consider this problem as a purposeful and organized process aimed at improvement of housing guarantees for combatants, their provision and protection.

The dialectical method was used in the study of categories, including combatants who took part in antiterrorist operation (ATO)/joint forces operation (JFO) and similar categories of individuals (disabled veterans, families of those who took part in antiterrorist operation (ATO)/joint forces operation (JFO), families of deceased combatants) entitled to receive housing free of charge, in determining the nature and specifics of the housing guarantee, when formulating proposals and recommendations for the application of legislation in the sphere of execution the right to housing by combatants and members of their families. 
Andriy P. Cherneha, Zhanna V. Udovenko, Nataliia A. Sergïenko, Nataliia O. Oblovatska y Alyona O. Dotsenko

The legal history method was used to study the state of scientific coverage of the topic, the evolution of changes in national legislation, case law, decisions of the Constitutional Court of Ukraine, the dynamics of increasing the number of those who took part in antiterrorist operation (ATO)/joint forces operation (JFO) over the past five years and a state of providing the appropriate category of citizens with housing (Kerimov et al., 2016).

The use of the legal comparative method allowed to determine the nature and relation between national and international law, civil, family, housing, criminal and specialized laws and regulations governing the provision of housing on a free of charge basis to citizens, servicemen, combatants who took part in antiterrorist operation (ATO)/joint forces operation (JFO) and members of their families. The formal logical method was used to define the basic concepts of the problematic issues of the study, as well as to substantiate proposals for improving national legislation in the sphere of ensuring and protecting the right to housing of combatants. The section on state guarantees of providing living space for combatants and persons equated to them contains a definition and a list of categories of individuals requiring the improvement of living conditions.

In the section on clarifying the issue of living space standards (norms) that a combatant can expect to be met, the issues of living space norms, standards for total living space, level of average living space per person are clarified. In the section on clarifying the issue of who is a family member of a combatant, there are various definitions of the category "family", which occurs in housing, family, civil, budget, tax and other codes and laws, criminal procedure, as well as interpretations of decisions of the Supreme Court of Ukraine and the Constitutional Court of Ukraine (Kuznetsov et al., 2018).

The system structure method provided an opportunity to systematize national and international laws and regulations, to study and analyse rules relevant for our research; to analyse the grounds, procedure (of regular and extraordinary provision of housing) and conditions for housing, monetary compensation for obtaining adequate living space. Statistics were used during the generalization of the number of combatants as of 2018-2020 and the dynamics of provision a housing to them in Ukraine for the last five years (2015-2020), the number of regulations and legal acts governing the implementation and protection the rights of combatants to housing, research, generalization and analysis of state statistical reports and the formation of theoretical conclusions based on them. 


\section{Results and Discussion}

\subsection{State guarantees of living space provision to combatants and persons equated to them: grounds and procedure}

In accordance with paragraph 14 of Article 12, paragraph 18 of Article 13 and paragraph 15 of Article 15 of the Law of Ukraine (1993) "On the Status of War Veterans, Guarantees of their Social Protection" the state guarantees the provision of housing for combatants and persons equated to them on a preferential basis. Such benefits may be received on an extraordinary basis by persons with disabilities as a result of war, families of deceased persons (items 5-8, paragraph 1 of Article 10 of the Law of Ukraine, 1993), persons who have disabilities of groups I-II due to wounds, blast injuries or illnesses received during direct participation in antiterrorist operation.

Combatants can be provided with housing on a preferential basis only in case they require improvement of living conditions. So in accordance with Art. 31 and 42 of the Housing Code of the Ukrainian SSR (1983) (hereinafter referred to as - "the Housing Code"), paragraph 13 of "Rules for registration of citizens requiring improvement of living conditions and providing them with housing in Ukrainian SSR", combatants and persons equated to them, are provided with living space if they require improvement of living conditions and are included in the relevant unified state register (Allalyev, 2019; Lapidus et al., 2018a; Lapidus et al., 2018b).

According to Art. 12 of the Law of Ukraine (1991) "On social and legal protection of military men and members of their families", individuals who have served in the military for 20 years or more, and members of their families are provided with accommodation for permanent residence or, if they wish, shall be provided with monetary compensation for obtaining adequate living space. So, in accordance to Art. 34 of the Housing Code (1983), those who require improvement of living conditions are individuals:

- provided with living space that does not meet the level determined in accordance with the procedure established by the State.

- living in a room that does not meet the established sanitary and technical requirements.

- who suffer from severe forms of some chronic diseases, which makes it impossible for them to live in a shared apartment or in the same room with their family members.

- living under an agreement of rent of residential premises in the buildings of state or public housing funds or under a contract of subrent of residential premises in the buildings of housing cooperatives. 
Andriy P. Cherneha, Zhanna V. Udovenko, Nataliia A. Sergïenko, Nataliia O. Oblovatska y Alyona O. Dotsenko

- who have lived for a long time (not less than 5 years) under a rent agreement in houses (apartments), that are private property of citizens.

- living in dormitories.

- two or more families living in the same room, regardless of family relations, or persons of different sexes older than 9 years, except for spouses.

- Internally displaced persons who have status of combatants, persons with disabilities as a result of war and members of their families, as well as family members of the deceased combatants.

Citizens requiring improvement of living conditions are registered for state and public housing and put into a unified state register of citizens requiring improvement of living conditions. Citizens requiring improvement of living conditions, who also live permanently and have registered place of residence in the given settlement are included into the register for housing. These requirements do not apply to internally displaced persons and citizens who enjoy the right of preferential and extraordinary provision of housing, and therefore to combatants (ATO veterans).

In accordance with Art. 36-39 of the Housing Code (1983), Section II of the Citizens Registration Rules and Instructions on the organization of providing servicemen of the Armed Forces of Ukraine and members of their families with living space, approved by the Resolution of the Ministry of Defence of Ukraine (2018) "About the Statement of the Instruction on the Organization of Providing Servicemen of Armed Forces of Ukraine and Members of their Families with Premises" including into the list (registration) for housing of citizens requiring improvement of living conditions is carried out:

- in the place of residence - by the decision of the executive committee of the district, city, district in the city, settlement, village Council of People's Deputies.

- on the place of employment - by a joint decision of the administration of the enterprise, institution, organization or cooperative enterprise or other public organization and the relevant labour union committee.

- At the place of service - by the housing (or joint housing) committee of each military unit.

The main objective of the Housing Committee (Joint Housing Committee) at each military unit is: inspection of living conditions of servicemen and members of their families; decision-making on housing issues, including consideration of relevant reports (applications) of 
servicemen and members of their families on housing issues; keeping records of servicemen who need to improve their living conditions by receiving service-provided accommodation (living space); keeping records of persons who need to improve their living conditions by receiving housing for permanent residence; consideration of applications, complaints and proposals that concern the work of housing committee at military units, and meetings with citizens on housing issues; issue of documents created by housing committees of military units and maintenance of operational records of service-provided housing.

In view of Article 2 of the Law of Ukraine (2004) "On Freedom of Movement and Free Choice of Place of Residence in Ukraine", citizens of Ukraine, as well as foreigners and stateless persons legally staying in Ukraine, are guaranteed freedom of movement and free choice of place of residence on its territory. According to the Fundamentals of Housing Legislation of the USSR and the Union Republics (1981), in cases and in accordance with the procedure established by the USSR Council of Ministers, the Citizens Registration Rules and other legal acts of the USSR Council of Ministers, citizens may be put into the register at the place other than the place of their residence. The application for housing registration is submitted to the executive committee of the village, settlement, city council, and village mayor at the place of residence of citizens or to the administration of the enterprise, institution, organization or cooperative enterprise or other public organization at the place of employment.

The application is signed by those family members who live together, have an independent right to receive housing and wish to be registered together. The application is submitted together with:

- certificates that confirm the place of residence of the person and each family member.

- certificates on whether family members are registered for housing at the place of their employment.

- citizens who are registered on preferential grounds or enjoy the right of priority or extraordinary provision of housing, indicate this in the application and submit the relevant documents.

- certificate that confirms a direct participation of a person in the antiterrorist operation or ensuring its conduct and protection of independence, sovereignty, and territorial integrity of Ukraine.

- certificate from the social service on registration in the unified state automated register of persons entitled to benefits, persons with disabilities because of war or status of a combatant or a family member of the deceased.

- copies of documents confirming the family relation of a person with a disability due to war or status of a combatant. 
Andriy P. Cherneha, Zhanna V. Udovenko, Nataliia A. Sergïenko, Nataliia O. Oblovatska y Alyona O. Dotsenko

- a copy of the certificate of a person with a disability due to war, or a status of a combatant.

In case the combatant is enlisted by contract, the following shall also be attached to the application: a report on enrolment in housing registration; extract from the order of appointment to the military unit; extract from the record of the personal file of the serviceman; certificate of military service from a military unit; certificate of family composition from the military unit; certificate from the last place of service on housing registration status; certificates from previous places of service on provision (non-provision, rent) of housing; certificate of whether family members are registered for housing at the place of residence, employment (military service); copies of ID documents of adult family members, birth certificates of minor family members, marriage certificate of a serviceman (Pogosyan, 2018; Pogosyan, 2019).

Consideration of applications for housing registration in the executive committee of the local Council of People's Deputies is carried out by the public board on housing issues of the executive committee, while at the enterprise, institution, organization applications are considered by the committee on communal services and housing of the labour union committee. These committees draw up an Act based on the results of the consideration. The decision on registration for housing must be made within one month from the date of submission of the necessary documents by the citizen.

Citizens are considered to be registered for housing: by the executive committee of the local Council of People's Deputies - from the date of the decision of the executive committee, at place of employment - from the date of a joint decision of the administration of the enterprise, institution, organization or cooperative enterprise or other public organization and corresponding labour union, approved by the executive committee of the local council (Gordadze et al., 2018).

Citizens registered for housing are put into the register book of persons who are in the waiting list for housing. For each citizen (family) in the housing register an accounting file that contains the necessary documents is created. Accounting files are kept at the place of citizens' registration for housing, and after providing them with housing - in the executive committee of the local Council of People's Deputies, which issued a permission to move in. Accounting files are stored for 5 years after the moment of provision of housing (or removal from the housing register). After the expiration of the specified period, cases are destroyed in accordance with the established procedure.

Regarding the procedure for registration of servicemen, it is regulated in detail by the Instruction on the organization of providing servicemen of 
the Armed Forces of Ukraine and members of their families with housing, approved by the Resolution of the Ministry of Defence of Ukraine (2018), that regulates rental of housing and payment of monetary compensation for sublease (rent) of residential premises; registration of persons who have acquired the necessary rights and need to improve living conditions by providing housing for permanent residence; provision of housing for permanent residence; payment of monetary compensation for obtaining a suitable housing, etc.

\subsection{Living space standard and conditions for receiving monetary compensation for housing}

The problem of order of housing provision to combatants and persons equated to them is resolved in accordance with paragraph 14 of Art. 12, paragraph 18 of Art. 13 and paragraph 15 of Art. 15 of the Law of Ukraine (1993) "On the Status of War Veterans, Guarantees of their Social Protection", Articles 43-46 of the Housing Code (1983). It should be noted, that the Housing Code establishes only the general order of priority for the provision of housing to citizens, and Art. 45 and 46, which regulate the issues of preferential and extraordinary provision of housing to certain categories of citizens, combatants (ATO veterans) and persons equated to them, do not recognize members of their families at all as having the appropriate rights. The only thing that indicates the possibility of applying these rules for the exercise of the relevant right is part 2 of Art. 45 and 46, which is blanket and contains a reference to other laws and regulations.

In accordance with paragraph 14 of Article 12 of the Law of Ukraine (1993) "On the Status of War Veterans, guarantees of their Social Protection", the primary right to be provided with a living space is granted to combatants. In addition, war veterans who were wounded, disabled or blast injured due to war or while performing their military service shall be provided with living space in two-year term from the date of registration for housing. In accordance with paragraph 18 of Article 13 and paragraph 15 of Article 15 of the Law of Ukraine (1993), the right to be provided with living space on an extraordinary basis is granted to individuals with disabilities due to war or which occurred as a result of wound, blast injury or illness, received during direct participation in the antiterrorist operation, as well as families of deceased combatants.

The categories of persons specified in these rules are provided with living space in two-year term from the date of registration for housing. The participants of hostilities on the territory of other countries who have disabilities of the group I shall be provided with housing during the year. 
Andriy P. Cherneha, Zhanna V. Udovenko, Nataliia A. Sergïenko, Nataliia O. Oblovatska y Alyona O. Dotsenko

In case of impossibility to provide combatants (ATO/JFO veterans), members of their families with housing on preferential basis, since 2016 the state has introduced a mechanism (procedure and conditions) for obtaining monetary compensation for obtaining suitable housing, guaranteed by Article 48-1 of the Housing Code (1983) and regulated by the Resolution of the Cabinet of Ministers of Ukraine No. 719, No. 214 and No. 280. Family members of the deceased combatants and persons with disabilities groups I and II as a result of the war; the combatants or persons with disabilities of group III as a result of war who have a status of internally displaced persons; persons with disabilities of the groups I and II as a result of war, members of families of combatants who took part in hostilities on the territory of other states were included by the law-makers into the category of people, who may receive monetary compensation (Resolution of the Cabinet of Ministers of Ukraine, 2016; Resolution of the Cabinet of Ministers of Ukraine, 2018a; Resolution of the Cabinet of Ministers of Ukraine, 2018b).

Persons from the above categories are entitled to compensation, if they require improvement of their living conditions and are registered for housing and are in the Unified state automated register of persons who are entitled to benefits. To receive compensation for the improvement of living conditions, you must apply in person, as a family member of the deceased or disabled combatant, or their legal representative or an authorized person to the social service at the place of registration for housing.

Monetary compensation to family members of the deceased persons or persons with disabilities is paid in full by the order of registration and taking into account the category of recipient of monetary compensation for family members of the deceased, within the funds provided by local budgets for compensation for housing. Family members of the deceased, whose death is related to direct participation in the antiterrorist operation, and who are on the housing register, receive compensation by category in the following order:

- $\quad$ category I - wife (husband) and minor children (including adopted before the date of death) who live with her (him); wife (husband) if the deceased has no children (including adopted).

- category II - minors (including adopted by a serviceman) if on the day of the person's death he (she) was divorced or, if not divorced, his wife (husband) was deprived of parental rights, or the deceased person was not divorced and his wife (husband) is not deprived of parental rights, but minor children live separately from his wife (husband); minor children of the deceased;

- $\quad$ category III - parents of the deceased.

- category IV - adult children who do not have (and did not have) their families. 
- category V - adult children who are recognized as persons with disabilities from childhood and have their own families.

- category VI - adult children, both parents of whom died or went missing.

- category VII - wife (husband), who at the time of death was deprived of parental rights in relation to minors of the deceased person, including adopted by the deceased, or, if not deprived of parental rights, minor children, including adopted by the deceased, live separately from his wife (husband).

In the event of a decision to award monetary compensation to the applicant, the commission shall determine its amount in accordance with the following standards: according to standard, 13.65 square meters of living space for each member of the family of the deceased, classified in one category, including the deceased, if he was on the housing register with members of his family; according to the norm, 13.65 square meters of living space per person with disability and each member of his family; according to the norm, 35.22 square meters of total area for family members of the deceased, who fall under one category, or for the family of a person with disability. Additionally, 10 square meters of living space per each member of the applicant's family who is a person with a disability or a child with disability (including the applicant). The amount of monetary compensation is calculated by the following formula:

$$
\mathrm{MC}=\left(13.65 \times \mathrm{N}_{\mathrm{c}}+35.22+\left(10 \times \mathrm{N}_{\mathrm{a}}\right)\right) \times \mathrm{I}_{\mathrm{c}} \times \mathrm{C}_{\mathrm{i}}+\mathrm{E}_{\mathrm{h}},(1)
$$

Where MC - monetary compensation; $\mathrm{N}_{c}$ - the number of family members of the deceased combatant that fall into one category or the number of family members of a person with disability for whom monetary compensation is calculated; $\mathrm{N}_{\mathrm{a}}$ - the number of family members of the applicant who are persons with disabilities or children with disabilities and who are entitled to monetary compensation, taking into account an additional 10 square meters of living space per each (including the applicant); $I_{c}$ - indirect cost (in UAH) of 1 square meter of total living space as for the settlement in which the applicant is registered as a person requiring improvement of living conditions as of the day of application for monetary compensation; $\mathrm{C}_{\mathrm{i}}$ - the coefficient of increase in the indirect cost of 1 square meter of total living space; $E_{h}$ - expenses (in UAH) related to the purchase of housing, registration of housing ownership and payment of taxes and fees (mandatory payments) provided by law.

For Kyiv, Dnipro, Lviv, Odesa and Kharkiv, the indirect cost increases 1.75 times; for cities that are regional centres, as well as for cities of regional 
Andriy P. Cherneha, Zhanna V. Udovenko, Nataliia A. Sergïenko, Nataliia O. Oblovatska y Alyona O. Dotsenko

significance with a population over 300 thousand -1.5 times; for cities of regional significance with a number of populations from 100 thousand to 300 thousand -1.25 times. In addition, according to the procedure of providing citizens with affordable housing, approved by the Resolution of the Cabinet of Ministers of Ukraine (2018a) programmes called " 50 for 50 " and " 70 for 30 " were established. According to these programmes, the state pays a certain part of the cost of real estate, in case of " 70 for 30 ", $30 \%$ of the value is paid by the state and the programme participant covers $70 \%$ (Some issues of providing citizens with affordable housing, 2018). However, if the " 70 for 30 " programme is designed for all citizens of Ukraine, then " 50 for 50 " aimed at combatants, servicemen and disabled due to war.

According to Art. 47 of the Housing Code of Ukraine, the norm of living space is set at 13.65 square meters per person. According to Part 1 of Art. 48 of the Housing Code of Ukraine, living space is provided to citizens within the norm of living space, but not less than the size of living space determined by the Cabinet of Ministers of Ukraine and the Federation of Labour Unions of Ukraine. Part 4 of this Article also states that a living space may be provided in excess of the norm of living space, if it consists of one room (one-room apartment) or is intended for persons of different sexes. In addition to the standard of living space, certain categories of citizens are provided with additional living space in the form of a room or in the amount of 10 additional square meters. Citizens suffering from severe forms of some chronic diseases, as well as citizens who need this area due to the conditions and nature of the work performed, the amount of additional living space may be increased.

In accordance with item 2 paragraph 58 of Citizens Registration Rules, if the living space is constructed by the state enterprises, associations and the organizations at the expense of funds which according to the legislation can be directed for the purposes of housing construction, premises are provided by the joint decision of administration and labour union committee to the committee of the relevant council on the provision of housing. In some cases, the legislation does not use the standard (norm) of living space, but the total living space. For example, according to the Law of Ukraine (1992) "On Privatization of State Housing Fund" privatization is carried out by free transfer to citizens of apartments (houses) at the rate of sanitary norm 21 square meters of total living space per tenant and each member of his family and an additional 10 square meters per family.

Actually, when establishing benefits for combatants (ATO veterans) for the use of housing and heating, law-makers also use the standard of 21 square meters of total living space for each person who permanently lives in a dwelling (house) and is entitled to a discount, and an additional 10.5 square meters per family. Therefore, the norm of living space should be distinguished from the norm of providing citizens with housing provided by 
Art. 48 of the Housing Code of Ukraine. This norm does not coincide with the level of actual provision of citizens with housing and is usually below this level.

\subsection{Execution of court decisions: the final stage of protection of right to housing of combatants (ATO/JFO veterans)}

As we have already covered such procedural guarantees as providing combatants (antiterrorist operation (ATO)/joint forces operation (JFO) veterans) and persons equated to them with housing, living space, and other guarantees regarding the maintenance and servicing of housing and their direct relation to the appropriate social status and category: a combatant/ war veteran; disabled due to war (groups I-III); a person with disability as a result of a wound, blast injury or illness received during direct participation in the antiterrorist operation; family member of the deceased combatant (antiterrorist operation (ATO)/joint forces operation (JFO) veterans).

In practice, a certain pattern of social services' attitude towards combatants and their family members has developed. This has led to a number of denials of using their preferences due to lack of marriage registration, lack of family ties, children's coming of age or marriage, and so on. By such, frankly, unprofessional behaviour or negligence in their duties, social services deprive defenders of Ukraine of their constitutional right to housing, forcing the latter to seek protection and restoration of violated rights in the courts. The cases reached the Supreme Court of Ukraine, while the Constitutional Court, 20 years ago, in 1999, made an official interpretation of "family member". All of these facts help to execute the right of servicemen, combatants and their families to housing, as the content of the interpretation of the legal concept of a "family member" unites several branches of law, including family and housing law.

The same position was held by the Grand Chamber of the Supreme Court in the decision in case No. 644/6274/16-ц noting that "The family consists of individuals who live together, are connected by common household, have mutual rights and responsibilities. A family is established on the basis of marriage, blood relation, adoption, as well as on other grounds not prohibited by law and not contrary to the moral principles of society" (Resolution of the Grand Chamber of the Supreme Court, 2018). According to item No. 5 paragraph No. 6 of the reasoning part of the Judgment of the Constitutional Court of Ukraine the case on official interpretation of a "family member" concept, family members of a serviceman are persons who constantly live together and have a common household. 
Andriy P. Cherneha, Zhanna V. Udovenko, Nataliia A. Sergïenko, Nataliia O. Oblovatska y Alyona O. Dotsenko

238 State Guarantees of the Right to Housing for War Veterans: Substantive and Procedural Aspects

Such persons include not only close relatives (brothers, sisters, grandchildren, grandparents), but also other relatives or persons who are not in direct family relation with the serviceman (brothers, sisters of the wife (husband); half brothers and sisters; stepfather, stepmother; guardians, trustees, stepsons, stepdaughters and others). Mandatory conditions for being recognized as family members, in addition to living together, are: common household, i.e. joint expenses, joint budget, joint meals, purchase of property for shared use, sharing costs for housing maintenance, its repair, provision mutual assistance, the presence of verbal or written agreements on the use of housing, other circumstances that testify the family relations (Resolution of the Grand Chamber of the Supreme Court, 2018).

We pay special attention to the fact that the relevant laws and regulations in the sphere of social protection of servicemen and combatants exclude from the list of their family members adult children who are married and have children of their own. However, the judicial practice has formed a completely opposite model for legal regulation of relevant relations by applying to such relations general principles of law and legislation (analogy of law) by combining family, housing and social legislation regarding servicemen and their family members. Thus, according to the decision of the Supreme Administrative Court of Ukraine (hereinafter referred to as "SACU") in the case No. K/800/66214/13, "An adult daughter of a serviceman who is married does not cease to be a member of his family, like her husband, if they live permanently with the employer and run a joint household with him" (2016).

The dispute arose due to the fact that by the decision of the housing committee of the military unit of the Ministry of Défense of Ukraine, the lieutenant colonel of the reserve was removed from the waiting list for housing on the basis of paragraph 1 part 2 of Art. 40 of the Housing Code (1983), as provided with housing in accordance with current legislation, namely: in connection with the his daughter's coming of age and her subsequent marriage; she is no longer dependent on her father and is no longer considered a member of the serviceman's family.

The SACU, upholding the decision of the court of first instance in the plaintiff's favour, reminded that lawmakers did not establish an exhaustive list of persons that fall into the category of family members of the tenant, but defined the criteria according to which persons not related by marriage or blood can be recognized as family. The court noted that the wife (husband), their children and parents are members of the serviceman's family and, along with him, enjoy housing and utilities if they live with him and, in cases provided by law, also run a common household. If adult children or parents have or start their own families, their family members are entitled to these benefits on an equal basis with other family members of the serviceman, but only if they are recognized as other members of the serviceman's family 
in accordance to Part 2 of Art. 64 of the Housing Code of the Ukrainian SSR (2017), i.e. as those who permanently live with the tenant and have a common household with him, and in compliance with the rules set out in Part 3 of the same article and Art. 65 of the said Code.

Having established legal framework for regulation of the execution of rights to housing by combatants (ATO/JFO veterans), the state does not always provide the possibility of such execution. Consequently, combatants (ATO/JFO veterans) are forced to apply to courts of different jurisdictions to protect their housing rights. However, a significant number of court decisions, including those on the rights to housing of antiterrorist (ATO)/ joint forces operation (JFO) veterans, involve enforcement measures.

For example, with regard to the above-mentioned Order of the Supreme Administrative Court of Ukraine (SACU) dd. 7 December 2016 in the case No. K/800/66214/13 (Housing Code of the Ukrainian SSR, 2017), that upheld the decision of the court of first instance, which imposed an obligation on one of the defendants (housing committee of the military unit A2309 of the Ministry of Defense) to take action (put the plaintiff families of four people on the register for housing). The obligation to act imposed to the debtor is subject to enforcement in accordance with the Art. 63 of the Law of Ukraine (2016) "On Enforcement Proceedings". The general procedure for such a measure of enforcement is as follows:

1. The executor on the next working day after 10 working days period (except for decisions subject to immediate execution) checks the execution of the decision by the debtor. If the decision is subject to immediate execution, the executor checks the execution of the decision no later than on the third working day after the opening of enforcement proceedings.

2. In case of non-execution of the decision by the debtor without good reason the executor issues a resolution on imposing of the penalty on the debtor, which also contains the requirement to execute the decision within 10 working days (or within three working days for the decision which is subject to immediate execution) and the warning on criminal liability.

3. The executor on the next working day after the expiration of the period provided above, checks the execution of the decision by the debtor.

4. In case of repeated non-execution of the decision by the debtor without good reasons, if such decision can be executed without participation of the debtor, the executor sends the notification on committing a criminal offense by the debtor to body of pretrial investigation and enforces the execution of the decision as prescribed by law. 
Andriy P. Cherneha, Zhanna V. Udovenko, Nataliia A. Sergïenko, Nataliia O. Oblovatska y Alyona O. Dotsenko

5. In case of non-execution of the decision, which cannot be executed without the participation of the debtor, the executor sends the notification on committing a criminal offense by the debtor to body of pre-trial investigation and makes a resolution on termination of enforcement proceedings (Law of Ukraine, 2016).

However, such a procedure for enforcement of court decisions does not seem to be effective enough in cases of the obligation to take action, in particular with regard to the right to housing of antiterrorist (ATO)/ joint forces operation (JFO) veterans. In particular, the procedure takes a long time and may not lead to a real restoration of housing rights of the antiterrorist (ATO)/joint forces operation (JFO) veterans. The lack of legislative technique is especially evident here: in case of non-execution of the decision, which cannot be executed without the debtor's participation, the executor must terminate the enforcement proceedings. The fact that the executor sends the notification on committing a criminal offense by the debtor to body of pre-trial investigation falls under the scope of another jurisdictional activity - criminal procedure - that provides no enforcement mechanisms for court decisions.

If we follow the correlation of the above-said with provisions of Art. 39 of the Law of Ukraine (2016) "On Enforcement Proceedings", which determine the grounds for termination of enforcement proceedings, it becomes clear that in the context of the grounds for termination of enforcement proceedings, these provisions do not correlate at all. In particular, Art. 39 of the Law of Ukraine (2016) "On Enforcement Proceedings" recognizes that one of the grounds for termination of enforcement proceedings is sending of an enforcement document to the court that issued it in cases provided for in part three of Art. 63 of this Law. But the third part of Art. 63 of the Law of Ukraine (2016) "On Enforcement Proceedings" does not refer to the sending of an enforcement document to the court. Thus, the rules of the Law of Ukraine (2016) "On Enforcement Proceedings" must correspond each other.

The issue of execution of the right of combatants (antiterrorist operation (ATO)/joint forces operation (JFO) veterans) to housing and the problems faced by war veterans in the process of improving their living conditions is a reflection of our legal reality, which makes it possible, due to a fairly large set of regulating legal acts and conflicts of law contained in them, to regulate relations in this sphere in different ways. Five years have passed since the introduction in 2015 of the state program of housing provision to those who took part in antiterrorist operation (ATO)/joint forces operation (JFO) on preferential basis, and the relevant issue is still not covered in scientific studies and periodicals. Some aspects of coverage of the implementation of their social rights by antiterrorist operation (ATO)/joint forces operation (JFO) veterans that can be found on state authorities' websites (such 
as Ministry of Justice of Ukraine, Ministry of Armed Forces of Ukraine, Ministry of Veterans Affairs, Ministry of National Police of Ukraine, Social Policy Department of Ukraine, state administrations, as well as local governments, public organizations) have informational nature only.

Over the past few years, a lot of attention of scientists in the field of law and public administration is focused on clarifying the legal status (including administrative and legal), regulatory and legal support of antiterrorist operation (ATO)/joint forces operation (JFO) veterans and persons equated to them. Such professionals as Burka (2016), Kondratenko (2015), Mykytiuk (2018), Honcharenko (2017), are worth mentioning in this context. In their works, they define basic concepts and categories of research, in particular, consider different approaches to understanding of the concept of "administrative and legal status of antiterrorist operation (ATO)/joint forces operation (JFO) veterans", clarify the meaning of "status", "legal status", "administrative and legal status", "antiterrorist operation" and "antiterrorist operation (ATO)/joint forces operation (JFO) veteran".

They formulate the author's definition of "the mechanism of state regulation of social protection of antiterrorist operation (ATO) veterans and members of their families", analyse the concepts of "antiterrorist operation (ATO) participant (veteran)" and "war veteran"; conduct a comprehensive study of the prerequisites for receiving of the administrative and legal status of antiterrorist operation (ATO) veteran and the elements of the administrative and legal status of an antiterrorist operation (ATO) veteran; carry out scientific and theoretical analysis of regulatory and legal support of social protection of antiterrorist operation (ATO) veterans and members of their families. However, the issues of provision, securing and protection of the right to housing for those who took part in antiterrorist operation (ATO)/joint forces operation (JFO) are practically not covered in scientific works and are mentioned only sporadically with references to the relevant law as a legal opportunity for this category of citizens. Moreover, the problems that veterans face when exercising their right to housing are not covered or analysed, and not generalized, both for the public awareness and for the legal, practical, and scientific purposes.

\section{Conclusion}

The state links the granting of the status of a participant in hostilities to the emergence of a number of benefits, which are aimed at making life easier for soldiers after returning to a peaceful life. One of the declared rights is the possibility of provision of housing by the state, but this privilege sometimes becomes a problem, because the demand for affordable housing far exceeds 
Andriy P. Cherneha, Zhanna V. Udovenko, Nataliia A. Sergïenko, Nataliia O. Oblovatska y Alyona O. Dotsenko

its supply. The number of ATO veterans, members of their families, disabled due to war, in the context of Russia's military aggression in eastern Ukraine, increases every year by at least 50 thousand, not counting other privileged categories, including those who took part in hostilities on the territories of other states and are still in a waiting list for provision of a living space.

During 2014-2019, the Ukrainian army underwent significant personnel and logistics changes. But the creation of a combat-ready army involves not only personnel changes and improved armaments, but also social support for military men, in particular, providing them and their families with sufficient living conditions. After all, living conditions directly affect the physical and psychological state and the morale of the defenders, while a well-off family is an additional motivation for exemplary military service and protection of the territory and sovereignty of the country. Another incentive to improve the physical and psychological condition of antiterrorist operation (ATO)/joint forces operation (JFO) soldiers is the confidence that their violated rights can be effectively protected before the court, and that the court decision, which formally protected their rights, including a right to housing, will be timely and impartially executed, in particular by enforcement proceedings.

The results of the study will be useful, first of all, for antiterrorist operation (ATO)/joint forces operation (JFO) veterans requiring the improvement of living conditions, as well as for human rights defenders who help combatants to exercise their right to housing. The analysis and overall conclusions presented in the article can also be used for consolidation of judicial practice, decisions of judicial and other state bodies, used for preparation of scholarly commentaries on housing, family and other codes and laws governing the execution and protection of a right to housing. The results of the research were tested at courses of law, round tables and conferences, workshops.

\section{Bibliographic References}

ALLALYEV, Ruslan. 2019. "Religious origins of the rule of law conception in the United States” In: Amazonia Investiga. Vol. 7, No. 14, pp. 212-217.

AN ADULT DAUGHTER OF A SERVICEMAN WHO IS MARRIED DOES NOT CEASE TO BE A MEMBER OF HIS FAMILY, LIKE HER HUSBAND, IF THEY LIVE PERMANENTLY WITH THE EMPLOYER AND RUN A JOINT HOUSEHOLD WITH HIM. 2016. Available online. In: https:// protocol.ua/ua/vasu_povnolitnya_donka_viyskovoslugbovtsya_ yaka_viyshla_zamig_ne_perestae_buti_chlenom_yogo_sim_i_ 
yak_i_ii_cholovik_yakshcho_voni_postiyno_progivayut_z_ naymachem_i_vedut_z_nim_spilne_gospodarstvo_(vasu_ sprava_k_800_66214_13_uhvala_vid_07_12_16_r_)/. Consultation date: $18 / 07 / 2020$.

BURKA, Alona. 2016. "Legal status of participants in the anti-terrorist operation and guarantees of their social protection" In: International Legal Bulletin: A Collection of Scientific Papers of the National University of the State Tax Service of Ukraine. Vol. 1, pp. 179-186.

CONSTITUTION OF UKRAINE. 2015. Available online. In: https://zakon.rada. gov.ua/laws/show/254к/96-вр\#Text. Consultation date: 18/07/2020.

FOR THE FIRST TIME IN 5 YEARS. 2019. The state budget-2020 provides funds for compensation for the destroyed housing in Donbass. Available online. In: https://vchasnoua.com/donbass/63016-vpershe-za-5rokiv-derzhbiudzhet-2020-peredbachaie-koshty-na-kompensatsiiu-zazruinovane-na-donbasi-zhytlo. Consultation date: 18/07/2020.

FUNDAMENTALS OF HOUSING LEGISLATION OF THE USSR AND THE UNION REPUBLICS. 1981. Available online. In: https://zakon.rada.gov. ua/laws/show/v5150400-81\#Text. Consultation date: 18/07/2020.

GORDADZE, Guram; KERIMOV, Vagif; GIRUTS, Maksym; POSHIBAEVA, Alexandra; KOSHELEV, Vladimir. 2018. "Genesis of the asphaltite of the Ivanovskoe field in the Orenburg region, Russia" In: Fuel. Vol. 216, pp. 835-842.

HONCHARENKO, Ganna. 2017. "Determining and granting the status of a participant in hostilities to employees of the Security Service of Ukraine who took part in the anti-terrorist operation" In: Prykarpattya Legal Bulletin. Vol. 4, pp. 48-53.

HOUSING CODE OF THE UKRAINIAN SSR. 1983. Available online. In: https://cis-legislation.com/document.fwx?rgn=8687. Consultation date: $21 / 07 / 2020$.

HOUSING CODE OF THE UKRAINIAN SSR (ISSUE). 2017. How to get housing for an anti-terrorist operation participant? Available online. In: https://www.ugorod.kr.ua/news/2017-11-04-61010.html. Consultation date: 18/07/2020.

INTERNATIONAL COVENANT ON ECONOMIC SOCIAL AND CULTURAL RIGHTS. 1973. Available online. In: https://zakon.rada.gov.ua/laws/ show/995_043. Consultation date: 18/07/2020. 
Andriy P. Cherneha, Zhanna V. Udovenko, Nataliia A. Sergïenko, Nataliia O. Oblovatska y Alyona O. Dotsenko

KERIMOV, Vagif; GORBUNOV, Aleksey; LAVRENOVA, Elena; OSIPOV, Alexander. 2015. "Models of hydrocarbon systems in the Russian Platform-Ural junction zone" In: Lithology and Mineral Resources. Vol. 50, No. 5, pp. 394-406.

KERIMOV, Vagif; GORDADZE, Guram; LAPIDUS, Albert; GIRUTS, Maksym; MUSTAEV, Rustam; MOVSUMZADE, Eldar; ZHAGFAROV, Fyrdaves; ZAKHARCHENKO, Maryia. 2018a. "Physicochemical properties and genesis of the asphaltites of Orenburg oblast" In: Solid Fuel Chemistry. Vol. 52, No. 2, pp. 128-137.

KERIMOV, Vagif; LEONOV, Mikhail; OSIPOV, Alexander; MUSTAEV, Rustam; HAI, Vu. 2019. "Hydrocarbons in the basement of the South China Sea (Vietnam) shelf and structural-tectonic model of their formation" In: Geotektonika. Vol. 53, No. 1, pp. 42-59.

KERIMOV,Vagif; MUSTAEV, Rustam; BONDAREV, Andrey. 2016. "Evaluation of the organic carbon content in the low-permeability shale formations (as in the case of the Khadum suite in the Ciscaucasia region)" In: Oriental Journal of Chemistry. Vol. 32, No. 6, pp. 3235-3241.

KERIMOV, Vagif; MUSTAEV, Rustam; OSIPOV, Alexander. 2018b. "Peculiarities of hydrocarbon generation at great depths in the crust" In: Doklady Earth Sciences. Vol. 483, No. 1, pp. 1413-1417.

KERIMOV, Vagif; RACHINSKY, Mykhayl; MUSTAEV, Rustam; SERIKOVA, Uliana. 2018c. "Geothermal conditions of hydrocarbon formation in the South Caspian basin” In: Iranian Journal of Earth Sciences. Vol. 10, No. 1 , pp. 78-89.

KONDRATENKO, Oleksiy. 2015. "General principles of normative-legal provision of public administration in the sphere of social protection of participants of anti-terrorist operation and members of their families" In: Bulletin of the National Academy of Public Administration under the President of Ukraine. No. 4, pp. 113-120.

KUZNETSOV, Nykolai; KERIMOV, Vagif; OSIPOV, Alexander; BONDAREV, Andrey; MONAKOVA, Aleksandra. 2018. "Geodynamics of the Ural foredeep and geomechanical modeling of the origin of hydrocarbon accumulations" In: Geotectonics. Vol. 52, No. 3, pp. 297-311.

LAPIDUS, Albert; KERIMOV, Vagif; MUSTAEV, Rustam; MOVSUMZADE, Eldar; SALIKHOVA, Irina; ZHAGFAROV, Fyrdaves. 2018a. "Natural bitumens: physicochemical properties and production technologies" In: Solid Fuel Chemistry. Vol. 52, No. 6, pp. 344-355. 
LAPIDUS, Albert; KERIMOV, Vagif; TRET'YAKOV, Valentyn; TALYSHINSKII, Rashyd; ILOLOV, Akhmadsho; MOVSUMZADE, Eldar. 2018b. "Extraction of Asphaltite with Toluene" In: Solid Fuel Chemistry. Vol. 52, No. 4, pp. 256-259.

LAW OF UKRAINE. 1991. On Social and Legal Protection of Military Men and Members of their Families. Available online. In: https://zakon.rada.gov. ua/laws/show/2011-12\#Text. Consultation date: 18/07/2020.

LAW OF UKRAINE. 1992. On Privatization of State Housing Fund. Available online. In: https://zakon.rada.gov.ua/laws/show/2482-12\#Text. Consultation date: 18/07/2020.

LAW OF UKRAINE. 1993. On the Status of War Veterans, Guarantees of their Social Protection. Available online. In: https://zakon.rada.gov.ua/laws/ show/3551-12\#Text. Consultation date: 18/07/2020.

LAW OF UKRAINE. 2004. On Freedom of Movement and Free Choice of Place of Residence in Ukraine. Available online. In: https://zakon.rada.gov. ua/laws/show/1382-15\#Text. Consultation date: 18/07/2020.

LAW OF UKRAINE. 2006. On Ratification of the European Social Charter. Available online. In: https://zakon.rada.gov.ua/laws/show/13716\#Text. Consultation date: 18/07/2020.

LAW OF UKRAINE. 2016. On Enforcement Proceedings. Available online. In: https://zakon.rada.gov.ua/laws/show/1404-19\#Text. Consultation date: $18 / 07 / 2020$.

MYKYTIUK, Diana. 2018. "Administrative and legal status of the participant of combat in Eastern Ukraine” In: Journal of Kyiv University of Law. No. 4, pp. 131-135.

POGOSYAN, Vardhes. 2018. "Philosophies of social behavior research: metaanalytic review” In: Wisdom. Vol. 11, No. 2, pp. 85-92.

POGOSYAN, Vardhes. 2019. "Change and variability of phenomena in complex social systems” In: Wisdom. Vol. 13, No. 2, pp. 95-103.

RESOLUTION OF THE CABINET OF MINISTERS OF UKRAINE. 2016. The Issue of Providing Housing for Certain Categories of Persons who Defended the Independence, Sovereignty and Territorial Integrity of Ukraine, as well as Members of their Families. Available online. In: https://zakon.rada.gov.ua/laws/show/719-2016-п\#Text. Consultation date: 18/07/2020. 
Andriy P. Cherneha, Zhanna V. Udovenko, Nataliia A. Sergïenko, Nataliia O. Oblovatska y Alyona O. Dotsenko

246 State Guarantees of the Right to Housing for War Veterans: Substantive and Procedural Aspects

RESOLUTION OF THE CABINET OF MINISTERS OF UKRAINE. 2018a. Issues of Providing Housing for Internally Displaced Persons Who Defended the Independence, Sovereignty and Territorial Integrity of Ukraine. Available online. In: https://zakon.rada.gov.ua/laws/ show/280-2018-п\#Text. Consultation date: 18/07/2020.

RESOLUTION OF THE CABINET OF MINISTERS OF UKRAINE. 2018b. The Issue of Providing Housing for Certain Categories of Persons who Took Part in Hostilities on the Territory of Other States, as well as Members of their Families. Available online. In: https://zakon.rada.gov.ua/laws/ show/214-2018-п\#Text. Consultation date: 18/07/2020.

RESOLUTION OF THE CABINET OF MINISTERS OF UKRAINE. 2018c. Provision of housing to certain categories of individuals who participated in hostilities on the territory of other states, as well as to members of their families. Available online. In: https://zakon.rada.gov.ua/laws/ show/214-2018-\%Do\%BF\#Text. Consultation date: 03/07/2020.

RESOLUTION OF THE CABINET OF MINISTERS OF UKRAINE. 2018d. Provision of housing to internally displaced persons who defended the independence, sovereignty and territorial integrity of Ukraine. Available online. In: https://zakon.rada.gov.ua/laws/show/280-2018\%Do\%BF\#Text. Consultation date: 18/07/2020.

RESOLUTION OF THE CABINET OF MINISTERS OF UKRAINE. 2019. On approval of the Procedure of using funds allocated from the state budget for provision of preferential long-term state credit for purchasing a housing to internally displaced persons, combatants who took part in antiterrorist operation (ATO)/joint forces operation (JFO). Available online. In: https://zakon.rada.gov.ua/laws/show/980-2019\%Do\%BF\#Text. Consultation date: 14/07/2020.

RESOLUTION OF THE GRAND CHAMBER OF THE SUPREME COURT. 2018. Criteria under which persons form a family No 14-283 цс 18. Available online. In: https://kzm.rv.court.gov.ua/sud1711/ gromadyanam/1/680150/. Consultation date: 18/07/2020.

RESOLUTION OF THE MINISTRY OF DEFENCE OF UKRAINE. 2018. About the Statement of the Instruction on the Organization of Providing Servicemen of Armed Forces of Ukraine and Members of their Families with Premises. Available online. In: http://search.ligazakon.ua/l_doc2. nsf/link1/RE32472.html. Consultation date: 18/07/2020.

SOME ISSUES OF PROVIDING CITIZENS WITH AFFORDABLE HOUSING. 2018. Available online. In: https://zakon.rada.gov.ua/laws/show/8192018-п\#Text. Consultation date: 18/07/2020. 
THE GOVERNMENT HAS ALLOCATED FUNDS FOR 500 APARTMENTS FOR ANTI-TERRORIST OPERATION PARTICIPANTS, DISPLACED PERSONS AND MAIDAN RESIDENTS. 2019. Available online. In: https://zik.ua/news/2019/o6/12/uryad_vydilyv_koshty_na_50o_ kvartyr_dlya_uchasnykiv_ato_pereselentsiv_i_1592401. Consultation date: $18 / 07 / 2020$.

THE NUMBER OF ANTI-TERRORIST OPERATION FIGHTERS WHO RECEIVED THE STATUS OF THE PARTICIPANT OF HOSTILITIES IS COUNTED. 2018. Available online. In: https://ua.news/ua/ pidrahovano-kilkist-bijtsiv-ato-yaki-otrimali-status-uchasnika-bojovihdij/. Consultation date: 18/07/2020.

THE NUMBER OF PARTICIPANTS IN HOSTILITIES WAS COUNTED BY THE MINISTRY OF VETERANS. 2019. Available online. In: https:// zik.ua/news/2019/o9/18/u_minveteraniv_porahuvaly_kilkist_ uchasnykiv_boyovyh_diy_1649001. Consultation date:18/07/2020.

UNIVERSAL DECLARATION OF HUMAN RIGHTS. 1948. Available online. In: https://zakon.rada.gov.ua/laws/show/995_015. Consultation date: 18/07/2020. 


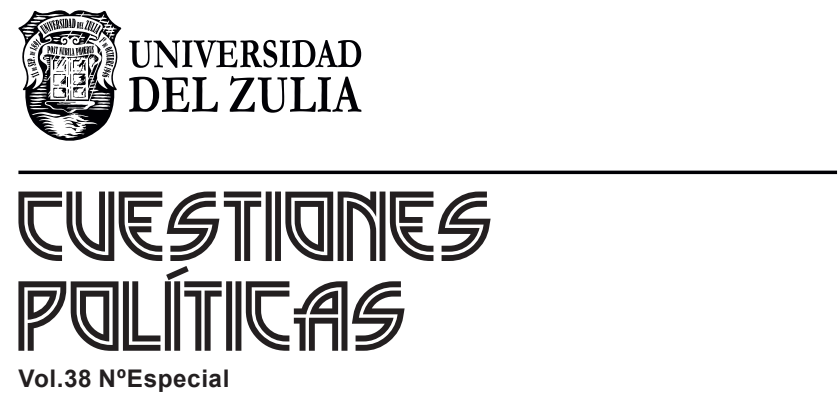

www.luz.edu.ve 